\title{
STRATEGI SEKOLAH DALAM MEWUJUDKAN VISI DAN MISI SMA DI KECAMATAN KASIHAN BANTUL
}

\author{
Dodi Ardi Kurniadi, Sugiyono \\ Prodi Manajemen Pendidikan PPs UNY, Fakulastas Teknik Universitas Negeri Yogyakarta \\ dikur333@gmail.com, sugiyono_1953@yahoo.com
}

\begin{abstract}
Abstrak
Penelitian bertujuan untuk: (1) mendeskripsikan proses perumusan visi dan misi sekolah; (2) mendeskripsikan strategi yang dibuat sekolah dalam upaya mewujudkan visi dan misi; (3) mendeskripsikan gambaran ketercapaian dari visi yang telah dibuat sekolah; (4) mengidentifikasi faktor yang mempengaruhi sekolah dalam upaya mewujudkan visi dan misi selama ini; dan (5) menemukan strategi yang efektif dalam mewujudkan visi dan misi yang telah dirumuskan sekolah. Penelitian menggunakan pendekatan kualitatif dengan jenis fenomenologi. Data dianalisis melalui proses pengumpulan data, reduksi data, penyajian data, dan penarikan kesimpulan. Hasil penelitian menunjukkan: (1) proses perumusan visi dan misi sekolah dilakukan melalui rapat internal yang dibuat oleh kepala sekolah dengan memperhatikan visi lembaga di atas sekolah, nilai-nilai dalam masyarakat, dan relevansi dengan perkembangan zaman; (2) strategi yang dibuat ketiga sekolah memang sedikit berbeda-beda namun pada dasarnya dapat dianalisis dengan dimensi proses, konten, dan konteks; (3) visi ketiga sekolah dapat dikatakan belum tercapai karena beberapa unsur yang ada di dalam visi belum sepenuhnya terwujud; (4) sumber daya manusia, pendanaan, metode, sarana prasarana, kepemimpinan sekolah, dan komunikasi mempengaruhi ketercapaian dari visi dan misi sekolah; dan (5) strategi yang efektif dalam upaya mewujudkan visi dan misi sekolah dapat dilakukan dengan cara membangun harapan individu menjadi visi bersama, membuat prioritas pembangunan dengan indikator ketercapaiannya, membangun motivasi berprestasi, meningkatkan partisipasi orang tua, dan membangun kemitraan dengan berbagai pihak.
\end{abstract}

Kata kunci: strategi mewujudkan visi dan misi

\section{STRATEGIES IN ACTUALIZING VISION AND MISSION SENIOR HIGH SCHOOL IN DISTRICT KASIHAN, BANTUL}

Dodi Ardi Kurniadi, Sugiyono

Prodi Manajemen Pendidikan PPs UNY, Fakulastas Teknik Universitas Negeri Yogyakarta dikur333@gmail.com, sugiyono_1953@yahoo.com

\begin{abstract}
This study aims to: (1) describe the formulation of schools' vision and missions; (2) describe the schools' strategies to actualize the vision and mission; (3) describe the illustration of vision and missions achievement formulated by schools; (4) identify factors that affect the schools in actualizing their visions and missions; and (5) find an effective strategy to actualize the vision and mission. The study used a qualitative approach with the type of phenomenology. Data were analyzed through the process of data collection, data reduction, data presentation, and conclusion. Results of the study: (1) the process formulation of schools' vision and missions was done by internal meeting conducted by the headmaster by considering higher institution's vision, values in society, and relevance of current development (2) strategies designed by those three schools are little bit different and can be basically analyzed with the dimension of process, content, and context (3) the schools' visions were said to be not yet achieved since some elements/components of vision and mission have not been completed (4) human's resource, funding, methods, facility and infrastructure, leadership in school, and communication affect the actualization of schools' visions and missions, and (5) effective strategy to actualize vision and missions of schools can be done by uniting individual expectation into shared vision, creating development priority along with its achievement indicator, building achievement motivation, increasing parent's participation, and building partnership with any stakeholders.
\end{abstract}

Keywords: strategy in actualizing vision and mission 


\section{Pendahuluan}

UNESCO pada tahun 2015 menetapkan perubahan visi untuk pendidikan yaitu ensure inclusive and equitable quality education and promote life-long learning opportunities for all (http://en.unesco.org). Hal ini berkaitan dengan pengembangan paradigma belajar dalam visi pendidikan menuju abad 21 mulai dari learning to think, learning to do, learning to live together, dan learning to be. Abad 21 memiliki ciri berkembangnya ilmu dan teknologi yang semakin canggih dan berpadu dengan ilmu sosial. Hal ini tentu akan berdampak pada pendidikan nasional karena Indonesia merupakan bagian dari masyarakat global.

D.I Yogyakarta merupakan salah satu provinsi yang menjadi barometer pendidikan nasional. Yogyakarta memiliki keunggulan komparatif yang ditandai dengan banyaknya pilihan pendidikan berkualitas pada semua jenjang, jalur, dan jenis pendidikan. Dinas Pendidikan, Pemuda, dan Olahraga D.I Yogyakarta membuat visi tahun 2012-2017 yaitu mewujudkan kualitas pendidikan, pemuda, dan olahraga yang menjunjung tinggi nilai-nilai luhur budaya. Dinas Pendidikan Menengah dan Non-Formal Kabupaten Bantul yang ada di bawahnya mencanangkan visi cerdas, berakhlak mulia, dan berkepribadian Indonesia (Dikpora D.I.Y, 2013).

Visi-visi yang ada, mulai dari visi pendidikan global sampai pada visi lembaga pendidikan yang ada di daerah seharusnya menjadi dasar bagi stakeholder untuk merumuskan visi sekolah. Sesuai dengan pandangan Hidayat \& Machali (2010, p.173) bahwa prosedur perumusan visi salah satunya perlu mengkaji makna visi satuan organisasi di atasnya untuk digunakan sebagai acuan. Tujuannya tentu agar ada kesesuaian dari setiap lembaga sehingga arah visi dapat jelas. Kejelasan visi dan misi sekolah berdasarkan hasil penelitian Akil (2007, p.271) memiliki pengaruh terhadap kinerja guru yang memberikan aspirasi, ide, cita-cita, gagasan, motivasi, dan inovasi dalam melaksanakan tugas-tugas pokoknya.
Sekolah sebagai lembaga penyelenggara pendidikan di level mikro realitanya memiliki visi yang berbeda-beda antarsekolah. Hal ini disebabkan adanya desentralisasi pendidikan yang membuat sekolah mendapat peluang untuk berkembang dan mengatur proses penyelenggaraan pendidikan sesuai dengan potensi lingkungan yang ada. Meskipun begitu pengelolaan pendidikan tetap harus mengacu pada kebijakan pemerintah.

Penelitian dilakukan di tiga sekolah yang disamarkan menjadi SMA X, SMA Y, dan SMA Z. Bertakwa, berprestasi, berkepribadian, dan ramah lingkungan merupakan visi SMA X. SMA Y memiliki visi menciptakan individu beriman dan bertakwa, berilmu pengetahuan dan teknologi, berprestasi, cinta seni dan budaya yang dijiwai oleh nilai-nilai budaya dan karakter bangsa, sehingga mampu bersaing di era globalisasi, sedangkan visi SMA Z adalah muslim cakap berakhlak mulia.

Berdasarkan hasil observasi awal diketahui SMA X sudah mengalami perubahan visi pada tahun 2012, sedangkan SMA Y dan SMA $Z$ belum pernah berubah. Visi SMA $X$ juga dicetak dan dipajang hampir di setiap ruangan di sekolah, berbeda dengan SMA Y dan SMA Z yang hanya memampang pernyataan visi di ruang kepala sekolah dan guru. Padahal sebaiknya visi ditunjukkan paling tidak di depan sekolah sebagai bagian dari sosialisasi sehingga orang tua siswa dapat mengetahui visi sekolah ketika ingin mendaftarkan anaknya.

Lampiran Permendiknas Nomor 19 Tahun 2007 tentang Standar Pengelolaan Pendidikan oleh Satuan Pendidikan Dasar dan Menengah menyebutkan bahwa "visi sekolah/madrasah disosialisasikan kepada warga sekolah/madrasah dan segenap pihak yang berkepentingan." Sosialisasi merupakan bagian dari komunikasi stakeholder untuk memberikan informasi akan pengelolaan sekolah kepada masyarakat. Permasalahannya sekolah kurang memperhatikan sosialisasi akan keadaan visi. Di dalam rapat pertemuan, sekolah lebih banyak membahas permasalahan terkait dengan pendanaan daripada membahas ke- 
tercapain visi dan misi. Hal ini yang menimbulkan anggapan bahwa visi hanya menjadi bagian dari formalitas untuk berdirinya sebuah sekolah.

Permasalahan lainnya, sekolah jarang melakukan evaluasi terhadap pencapaian dari visi secara menyeluruh karena cenderung berfokus pada aspek kognitif siswa yang diukur dari perolehan nilai ujian nasional. Hal ini disebabkan paradigma masyarakat bahwa kemampuan siswa dapat dilihat dari tinggi rendahnya nilai. Padahal pembangunan pendidikan nasional dalam Renstra Depdiknas diharapkan dapat mencakup tiga dimensi kemanusiaan yaitu afektif, kognitif, dan psikomotor. Tiga dimensi tersebut berdasarkan pandangan Danim (2007, p.45) masuk dalam substansi produk yang merupakan bagian dari tupoksi sekolah.

Sekolah menurut Rivai \& Murni (2012, p.195) adalah "sistem sosial terbuka dengan lima elemen penting yaitu perorangan, struktural, kebudayaan, politik, dan pendidikan". Budaya di sekolah dapat dikatakan merupakan hasil dari proses pembelajaran yang berhubungan dengan nilai, keyakinan, dan kebiasaan yang dikembangkan oleh warga sekolah. Oleh sebab itu visi secara tidak langsung ikut memberikan arah terhadap kultur yang akan dibangun dan dikembangkan dalam ruang lingkup akademis di sekolah. Sesuai dengan teori Ekselensi (Zamroni, 2007, p.10) menggambarkan bahwa "visi dan misi akan berdampak pada mutu proses pembelajaran di sekolah yang dipengaruhi oleh infrastruktur dan kultur".

Visi memang tidak akan dapat langsung terwujud di sekolah. Visi sebaiknya dicapai secara bertahap karena pada dasarnya prosesnya membutuhkan waktu untuk melihat hasilnya. Hal ini sesuai dengan prinsip total quality management yang diungkapkan Sallis (2010, p.76) bahwa "perbaikan tanpa henti hingga tujuan organisasi dapat dicapai dan dengan melibatkan segenap komponen dalam organisasi tersebut." Perbaikan berkelanjutan dengan berfokus pada siswa menjadi modal utama dalam membangun sekolah yang efektif.
Untuk itu, stakeholder di sekolah perlu menyusun strategi sesuai dengan keadaan dan sumber daya yang dimiliki.

Strategi setiap sekolah untuk mewujudkan visi mungkin beberapa bagian ada yang sama dan ada yang berbeda. Hal ini tergantung dari sudut pandang kepala sekolah sebagai pimpinan karena strategi dapat mengadopsi dari sekolah lain yang sudah berhasil dan menerapkannya kepada siswa. Menurut Johnson \& Scholes (Fidler, 2002, p.9) mengatakan bahwa:

Strategy is the direction and scope of an organisation over the long term which achieves advantage for the organisation through its configuration of resources within a changing environment, to meet the needs of markets and to fulfil stakeholder expectations.

Strategi secara otomatis akan berdampak pada kinerja kepala sekolah dan guru. Guru lebih condong pada mengatur proses pembelajaran untuk siswa di kelas, berbeda dengan kepala sekolah yang memiliki tanggung jawab dalam mengelola seluruh proses pendidikan di sekolah dan berupaya mempertahankan eksistensinya. Meskipun begitu, perlu adanya sinergi dari masing-masing pihak untuk saling membantu menyelesaikan tugas karena keberhasilan sekolah untuk melakukan perbaikan berkelanjutan sangat ditentukan oleh kesatuan peran aktor pelaksana strategi di dalamnya. Sebagus apapun strategi yang dibuat dalam upaya mewujudkan visi sekolah tetap memerlukan dukungan seluruh pihak yang terkait.

\section{Metode Penelitian}

Pendekatan yang digunakan dalam penelitian ini adalah kualitatif dengan jenis penelitian fenomenologi. Penelitian ini dilaksanakan pada bulan Februari sampai April 2015. Tempat yang digunakan dalam penelitian merupakan tiga sekolah di Kecamatan Kasihan yang peneliti samarkan menjadi SMA X, SMA Y, dan SMA Z. Sumber data penelitian ini meliputi: kepala sekolah, wakil kepala sekolah, perwakilan guru, dan kepala staf TU. Subjek merupa- 
kan orang-orang yang mengetahui, terlibat, dan menjadi aktor dalam proses perumusan sampai pada pelaksanaan strategi dalam upaya mencapai visi dan misi sekolah.

Data penelitian ini berupa data kualitatif. Teknik pengumpulan data meliputi observasi, wawancara, dan analisis dokumen. Instrumen penelitian berupa pedoman observasi dan pedoman wawancara. Teknik analisis data yang dilakukan dalam penelitian ini mengadopsi teknik analisis Miles \& Huberman (Sugiyono, 2014, p.405) yang terdiri dari beberapa langkah yaitu meliputi pengumpulan data, reduksi data, penyajian data, dan penarikan kesimpulan.

\section{Hasil Penelitian dan Pembahasan}

\section{Hasil Penelitian}

Visi SMA $\mathrm{X}$ adalah adalah unggul imtak, terdidik, dan berkualitas. Proses perumusan visi dilakukan pada rapat kerja tahunan sekolah, visi dirundingkan dengan dikomandoi oleh kepala sekolah. Di dalam rapat, kepala sekolah meminta pandangan dari guru dan karyawan agar mendapatkan inspirasi atau ide akan pernyataan visi yang diinginkan. Gagasan-gagasan dicermati dengan mencari literatur dan relevansi terkait dengan pernyataan visi.

Hasil rapat internal menyimpulkan kata unggul dan berkualitas masih sulit untuk diukur sehingga pada tahun 2012 sekolah kemudian mengganti visi menjadi bertakwa, berprestasi, berkepribadian, dan ramah lingkungan. Meskipun mengalami perubahan, visi tersebut dipandang Wakil Kepala Sekolah Urusan Humas masih sejalan dengan visi Dinas Pendidikan Menengah dan Non Formal Kabupaten Bantul yaitu cerdas, berakhlak mulia, dan berkepribadian Indonesia. Selain itu visi yang pendek diharapkan dapat mudah diingat oleh warga sekolah sehingga memotivasi untuk menjadi apa yang diharapkan dalam visi tersebut.

SMA X merupakan salah satu dari enam sekolah di Kabupaten Bantul yang ditunjuk sebagai pilot project untuk tetap menggunakan Kurikulum 2013. Kelebihan yang dimiliki sekolah diantaranya: (1) kualitas siswa yang masuk sudah baik, (2) jumlah guru yang mencukupi dengan latar belakang bidang studi yang sesuai, (3) sarana prasarana yang melebihi Standar Nasional Pendidikan, (4) dukungan orang tua dan masyarakat yang cukup kuat terhadap perkembangan sekolah. Namun ada kelemahan yang perlu segera diperbaiki sekolah seperti transparansi data, motivasi siswa yang naik turun, sampai kesadaran guru dan siswa dalam merawat fasilitas sekolah.

SMA X membuat banyak program dalam upaya mewujudkan visi dan misi. Berkaitan keagamaan selain melalui pelajaran agama, ada program pembinaan imtak siswa yang dilaksanakan setiap hari. Dalam hal prestasi, siswa diberikan pembinaan, pendampingan, pembimbingan dalam kegiatan intrakurikuler dan ekstrakurikuler sesuai dengan minat dan bakat siswa sehingga dapat bersaing di tingkat nasional maupun global.

Penanaman nilai kejujuran dilakukan melalui pengadaan kotak kehilangan. Hal ini dimaksudkan agar kepribadian siswa berkembang. Untuk kedisiplinan siswa harus mengisi kartu izin ketika akan keluar dari sekolah. Aturan yang jelas juga dibuat bagi seluruh warga sekolah dan akan ada reward dan punishment bagi yang melaksanakan ataupun melanggarnya. Terkait visi ramah lingkungan, sekolah berupaya $\mathrm{m}$ enerapkan pembiasaan hidup bersih pada siswa, hidup hemat, dan mencintai lingkungan. Sekolah berupaya melakukan penambahan dan penjagaan tanaman hijau.

Kendala yang dihadapi SMA $X$ dalam upaya mewujudkan visi dan misi salah satunya adanya pro dan kontra dalam pembuatan dan pelaksanaan program sekolah. Kurangnya kesadaran guru dan siswa dalam merawat fasilitas juga menjadi kendala karena sarana prasarana merupakan bagian penting dalam proses pembelajaran. Selain itu motivasi siswa yang naik turun perlu menjadi perhatian seluruh pihak.

Visi SMA X tercapai melalui program-program yang dijalankan sekolah. 
Setiap hari ada ibadah rutin yang dilakukan oleh siswa baik Islam, Katolik, atau Kristen. Siswa melaksanakan ibadah sesuai dengan keyakinannya masing-masing dan mampu bertenggang rasa tanpa mendeskriminalisasi satu agama. Prestasi siswa pun cukup membanggakan karena setiap tahun meraih juara baik akademik maupun nonakademik. Dari segi kepribadian, nilai yang diandalkan dari siswa ada pada kejujuran, kedisiplinan, dan tanggung jawab, sedangkan pada ramah lingkungan, siswa diajarkan hidup sehat dan hemat.

Visi SMA Y adalah menciptakan individu beriman dan bertakwa, berilmu pengetahuan dan teknologi, berprestasi, cinta seni dan budaya yang dijiwai oleh nilai-nilai budaya dan karakter bangsa. Berdasarkan temuan, hanya beberapa guru yang terlibat dalam proses perumusan visi karena visi sekolah sudah lama tidak mengalami perubahan. Meskipun begitu rumusan visi SMA Y tetap dibahas melalui rapat pleno dan uji publik yang melibatkan seluruh warga sekolah.

Kekuatan SMA Y terletak pada guruguru yang ulet, sabar, terampil, serta mau mendampingi siswa dengan memberikan motivasi dan arahan. Guru juga hafal dengan siswa karena jumlahnya yang sedikit. Namun hal ini menunjukkan bahwa SMA Y masih belum diminati oleh masyarakat. Kelemahan lainnya, anggaran yang dimiliki sekolah terbatas sehingga berdampak pada minimnya sarana prasarana yang dimiliki sekolah. Selain itu masyarakat cenderung kurang percaya terhadap produktivitas SMA Y karena lulusan belum dapat bersaing di perguruan tinggi dan dunia kerja.

SMA Y memiliki beberapa strategi dalam upaya mewujudkan visi dan misi. Sekolah membuat prioritas dalam rangka pengembangan sekolah dan prioritas sekolah saat ini yaitu memperbaiki karakter siswa. Proses pembelajaran harian menjadi program utama untuk mendidik siswa. Di bidang keagamaan, sekolah berupaya terus meningkatkan keimanan dan ketakwaan untuk memperkuat kepribadian siswa sesuai dengan insan beragama. Pihak sekolah mempunyai program reward dan punishment untuk siapa saja yang berprestasi dan juga dalam upaya menciptakan kedisiplinan serta ketertiban.

Meskipun sarana prasarana sekolah minim, guru-guru berupaya mengoptimalkan apa yang ada untuk proses pembelajaran siswa. Guru memanfaatkan internet, koran, dan majalah sebagai media belajar. Selain itu guru memberikan motivasi di setiap proses pembelajaran sehingga harapannya prestasi siswa dapat meningkat baik akademik maupun nonakademik. Untuk meningkatkan kemampuan guru, sekolah juga memberikan pembinaan dan pelatihan sesuai dengan kebutuhan yang diperlukan.

SMA Y termasuk sekolah yang kecil. Sekolah hanya memiliki dana yang terbatas. Dampaknya, minimnya fasilitas penunjang pembelajaran yang dapat disediakan sekolah. Kendala lainnya terletak pada input siswa yang tergolong rendah sehingga motivasi belajar yang kurang. Selain itu guru SMA Y belum terlalu mengoptimalkan buku-buku perpustakaan untuk menjadi sumber belajar.

Pencapaian visi di SMA Y secara umum belum terlalu terlihat. Sebagian besar misi belum dapat terlaksana baik dari upaya meningkatkan iman dan takwa siswa, pengembangan budaya membaca, sampai pada kualitas output untuk melanjutkan ke perguruan tinggi. Hal ini tidak lepas dari pengaruh input yang rendah dan fasilitas sekolah yang terbatas.

Visi SMA Z berpedoman pada dua instansi yaitu yayasan dan juga pemerintah sehingga proses perumusan visi tidak lepas dari keduanya. Perumusan visi melibatkan seluruh warga sekolah dengan memperhatikan keluwesan, kepadatan, dan kemudahan untuk diingat. Rapat bukan hanya membahas tentang pernyataan visi akan tetapi juga membahas akan bagaimana pengelolaan sekolah, kebutuhan guru, dan rencana kegiatan dan anggaran sekolah. Setelah visi disetujui secara bulat maka akan diturunkan menjadi misi sekolah yang nantinya akan disosialisasikan.

Keadaan SMA $Z$ tidak jauh berbeda dengan SMA Y. Pendanaan yang terbatas 
dengan input siswa yang rendah menjadi kelemahan sekolah. Siswa juga kurang termotivasi untuk belajar dan sering terlambat datang ke sekolah. Namun diantara kelemahan, SMA Z memiliki kelebihan seperti kerja sama antara kepala sekolah, guru, dan karyawan untuk mengembangkan sekolah. Selain itu komunikasi yang terjalin baik dengan Yayasan Muhammadiyah dan masyarakat dapat dikembangkan untuk kemajuan sekolah.

Berbeda dengan SMA X dan SMA Y, SMA Z memiliki tujuh jam dalam pelajaran Agama Islam. Selain itu untuk mewujudkan visi khususnya dalam bidang akademik dan nonakademik, guru berupaya secara bertahap menaikkan kriteria ketuntasan minimal siswa. Pada jam istirahat, guru juga mempersilahkan siswa untuk bertanya terkait materi pelajaran yang belum mereka pahami. Bahkan siswa diperbolehkan meminjam buku-buku perpustakaan tanpa harus kerepotan mengurus kartu pinjaman. Berkaitan dengan keterampilan, siswa SMA Z diberikan pelajaran tata busana, tapak suci, dan TI. Sekolah berupaya tetap berkomunikasi dengan orang tua melalui program home visit. Hal ini diupayakan agar orang tua dapat terlibat aktif membina dan memotivasi siswa.

SMA Z terkendala dalam masalah pendanaan yang terbatas. Bantuan pemerintah dirasa kurang mencukupi karena diberikan berdasarkan jumlah siswa. Padahal siswa yang bersekolah di SMA Z sangat sedikit. Siswa yang mendaftarpun dipandang memiliki input yang rendah. Hal ini berdampak pada motivasi siswa yang kurang dalam mengikuti proses pembelajaran. Siswa kurang berkonsentrasi dan bahkan bolos. Fasilitas penunjang yang minim juga menjadi kendala lain yang masih berupaya dipecahkan pihak sekolah.

Tekait dengan ketercapaian visi, keadaan SMA $Z$ tidak jauh berbeda dengan SMA Y yang masih jauh dari harapan. Memang beberapa program sudah berjalan seperti program keagamaan baik yang harian atau berkala, melaksanakan pembelajaran intensif untuk pengembangan potensi akademik dan nonakademik, dan program pembekalan keterampilan. Namun tidak pelaksanaan program masih belum optimal karena berkaitan dengan kepribadian siswa.

\section{Pembahasan}

\section{Perumusan Visi dan Misi Sekolah}

Pada dasarnya setiap sekolah sudah pasti memiliki visi yang menjadi pedoman arah ke mana sekolah akan dituju. Perumusan visi merupakan bagian dari proses pengelolaan sekolah yang melibatkan banyak pihak, baik internal maupun eksternal. Oleh sebab itu seluruh stakeholders mulai dari kepala sekolah, guru, karyawan, orang tua, komite, yayasan, dan pemerintah bertanggung jawab terhadap proses yang ada mulai dari perumusan sampai pada mengevaluasi keberhasilan dan ketercapaian dari visi sekolah.

David (2011, pp.46-47) menjelaskan proses pengembangan pernyataan visi dan misi perlu keterlibatasan semua manajer dengan maksud agar adanya komitmen mereka untuk organisasi. Pandangan David tersebut sesuai dengan apa yang terjadi di SMA X, SMA Y, dan SMA Z. Manajer di sekolah merujuk pada kepala sekolah dibantu dengan wakil-wakil kepala sekolah. Peran kepala sekolah dengan wakil kepala sekolah memang besar terutama dalam pencetusan ide akan pernyataan awal visi.

Proses perumusan visi dilakukan melalui rapat internal yang diadakan oleh kepala sekolah. Di dalam rapat, kepala sekolah membuat tim yang terdiri dari wakil-wakil kepala sekolah mulai dari urusan kurikulum, sarana prasarana, kesiswaan, hubungan masyarakat, dan beberapa guru. Tim ini memiliki tugas untuk mengumpulkan informasi dari berbagai sumber dengan memperhatikan beberapa hal berikut: (1) visi lembaga yang ada di atas sekolah; (2) nilai-nilai dalam masyarakat; (3) relevansi dengan tuntutan dan perkembangan zaman.

Gagasan pernyataan visi kemudian dipaparkan dalam pertemuan yang melibatkan seluruh stakeholder termasuk komite, yayasan, orang tua, dan perwakilan 
dinas pendidikan setempat. Setelah ada kesepakatan, kemudian visi akan diputuskan kepala sekolah dihadapan stakeholder yang hadir. Visi yang sudah diputuskan kemudian diturunkan menjadi misi sebagai langkah untuk mencapai visi tersebut. Misi yang dibuat sekolah biasanya dalam bentuk poin-poin. Visi dan misi sekolah kemudian disosialisasikan oleh wakil kepala sekolah humas kepada masyarakat.

Visi SMA X dan SMA Z terbilang singkat, padat, dan mudah diingat. Sedikit berbeda pada visi SMA Y yang cukup panjang karena memiliki 28 jumlah kata. Dampaknya guru dan karyawan terkadang lupa akan pernyataan visi sekolah. Hal tersebut membuat peneliti menyimpulkan bahwa visi SMA Y dipandang kurang menarik oleh beberapa guru dan karyawan. Padahal Kantabutra (2012, p.1162) menyebutkan bahwa "visi harus singkat, jelas, bersifat abstrak, mencerminkan stabilitas, berorientasi ke depan, memiliki tantangan, dan menginspirasi."

Meskipun visi SMA Y cukup panjang, namun apabila diperhatikan visi tersebut masih bersifat inspiratif dan menantang sama dengan visi SMA $X$ dan SMA $Z$. Hal ini disebabkan karena visi tersebut merupakan suatu yang ideal yang ingin dicapai sekolah. Bahkan visi ketiga sekolah memungkinkan untuk berubah sesuai dengan perkembangan zaman dan keinginan dari kepala sekolah sebagai pimpinan. Selain itu, visi sekolah berorientasi pada masa depan sehingga memungkinkan untuk setiap bagian ikut berperan dalam pelaksanaannya.

\section{Strategi Sekolah Mewujudkan Visi dan Misi}

Hannagan (2002, p.14) menyebutkan ada tiga dimensi dari strategi, diantaranya yaitu: (1) dimensi proses; (2) dimensi konten; (3) dimensi konteks.

\section{Dimensi Proses}

Proses akan sebuah strategi tidak lepas dari fungsi-fungsi manajemen mulai dari perencanaan sampai pada pengendalian. Pada tahap perencanaan, ketiga sekolah baik SMA X, SMA Y, dan SMA Z membuat strategi dengan melihat keadaan dan kondisi yang sekolah. Mereka melakukan analisis terhadap kekuatan, kelemahan, peluang, dan ancaman yang dimiliki sekolah.

Pada tahap pengorganisasian merupakan proses yang berkaitan dengan sosialisasi dan pembagian tugas sebagai penanggung jawab, sedangkan pelaksanaan berhubungan dengan upaya realisasi strategi. Namun secara tidak langsung sebenarnya tugas tersebut sudah dibebankan kepada masing-masing pihak seperti kepala sekolah sebagi manajer sekaligus pimpinan, guru tugasnya mengajar di kelas, dan wakil-wakil kepala sekolah sudah memegang tugasnya membantu kepala sekolah untuk urusan kurikulum, kesiswaan, sarana prasarana, dan humas.

Untuk pengendalian, di sekolah melakukan evaluasi secara teratur dan terencana. Biasanya evaluasi dilakukan dengan mengadakan rapat guru dan karyawan yang bertujuan untuk mengetahui perkembangan dari strategi. Apabila ditemukan permasalahan misalnya berkaitan dengan nilai siswa yang kurang memuaskan, maka nanti pada rapat tengah dan akhir semester akan dikemukakan kepada orang tua siswa. Pengendalian semacam ini dimaksudkan agar ada komunikasi yang terjalin antara sekolah dan orang tua sehingga ketika ada masukan atau pandangan positif dapat ditampung dan selanjutkan didiskusikan bersama.

\section{Dimensi konten}

SMA X, SMA Y, dan SMA Z memiliki strategi yang mendekati sama dalam aspek spiritual keagamaan. Untuk kegiatan harian, sekolah mengadakan ibadah sesuai dengan kepercayaan siswa seperti ibadah wajib atau Sunnah. Perbedaannya di SMA Y dan SMA Z seluruh siswa beragama Islam, sedangkan di SMA $X$ selain agama Islam, ada agama Kristen, Katolik, dan Hindu. SMA $X$ juga memiliki fasilitas penunjang Masjid Al-Hikmah dan ruang peribadata nagama Kristen, sedangkan SMA Y dan SMA Z hanya memiliki sebuah mushola.

Di dalam kurikulum sekolah, materi pelajaran keagamaan diberikan kepada sis- 
wa oleh guru yang sesuai dengan agamanya. Namun ada perbedaan jumlah pelajaran di ketiga sekolah. SMA X dan SMA Y materi pelajaran agama di kelas hanya tiga jam, sedangkan SMA Z mencapai tujuh jam pelajaran. Hal ini disebabkan SMA Z menggunakan kurikulum Al-Islam, Kemuhammadiyahan, dan Bahasa Arab yang memang wajib diajarkan pada sekolah-sekolah di bawah naungan Muhammadiyah.

Dari aspek kognitif, ada beberapa strategi yang sama diantara ketiga sekolah seperti pendalaman materi bagi siswa kelas XII sebagai persiapan menghadapi ujian nasional. Selain itu sekolah juga memberikan kesempatan untuk siswa mengikuti berbagai perlombaan akademik sebagai langkah untuk memberikan pengalaman dan mengukur kemampuan siswanya. Di SMA $X$ ada proses seleksi dan pembimbingan siswa yang ingin mengikuti olimpiade bidang studi. Berbeda dengan SMA Y dan SMA $Z$ yang siswanya sedikit sehingga biasanya sekolah yang menunjuk siapa yang dianggap mampu mewakili sekolah.

Perbedaan yang paling mencolok diantara ketiga sekolah adalah berhubungan dengan sumber daya. Berdasarkan hasil penelitian, SMA $X$ memiliki dana yang cukup besar untuk mengelola sekolah. Hal ini membuat sekolah dapat membuat strategi tanpa harus terlalu memikirkan tentang pembiayaan. Sekolah berupaya memfasilitasi siswa dalam proses pembelajaran denganmenyediakan LCD dan AC di setiap ruangan. Selain itu sekolah juga menambahkan bandwidth untuk hotspot yang dapat digunakan siswa ketika mencari sumber belajar lain dari internet.

Dari Aspek afektif, setiap sekolah membuat tata tertib yang harus dipatuhi oleh seluruh warga sekolah, mulai dari seragam, jam masuk, dan aturan lainnya. Setiap sekolah juga melaksanakan upacara bendera, pelatihan dasar kepemimpinan, dan menanamkan siswa agar ramah lingkungan dengan menjaga kebersihan. Obong, Okey, Aniah, et al (2010, p.196) menyebutkan bahwa "lingkungan sekolah yang baik dan bersih dapat meningkatkan pengajaran dan pembelajaran yang efektif serta mempromosikan hidup sehat di sekolah." Namun walaupun memiliki program yang sama, implementasi yang terjadi di ketiga sekolah sedikit berbeda.

Di SMA X aturan akan kedisiplinan sangat ketat sehingga siswa patuh mentaatinya. Namun berbeda dengan SMA Y dan SMA $Z$ yang siswanya terkadang malas dan kurang motivasi untuk belajar di sekolah sehingga tidak jarang melanggar beberapa peraturan sekolah. Selain itu, pelaksanaan upacara bendera dilaksanakan hanya dua kali yaitu pada awal dan akhir setiap bulan. Bahkan di SMA Z upacara dilaksanakan pada jam kedua pelajaran karena biasanya siswa yang datang baru sedikit. SMA $X$ juga membuat program bakti sosial seperti pembagian sembako atau bantuan kepada anak-anak yatim. Kegiatan tersebut bertujuan untuk mengetuk hati siswa dan berbagi kepada sesama yang membutuhkan. Berbeda dengan apa yang terjadi di SMA Y dan SMA Z yang sebagian besar merupakan golongan yang kurang mampu sehingga lebih banyak mendapatkan bantuan.

SMA X memiliki unsur ramah lingkungan dalam visinya sehingga berupaya mengembangkan pembiasaan hidup sehat dan bersih. Hal ini dilakukan dengan kegiatan piket kelas, gotong royong, sampai pada kontrol makanan yang dijual di sekolah. Berdasarkan pengamatan, SMA X dan SMA Z membuat slogan-slogan yang dipajang di sekitaran sekolah. Slogan yang dipajang beragam, ada yang berkaitan dengan ramah lingkungan, larangan menggunakan narkoba, kebersihan, dan budaya senyum, salam, sapa, sopan, serta santun. Namun slogan-slogan tidak peneliti temukan di SMA Y sehingga hal ini perlu diperhatikan sebagai salah satu langkah mengembangkan kultur positif kepada warga sekolah.

Aspek psikomotor berkaitan dengan keterampilan yang dimiliki oleh siswa. Aspek ini sebenarnya sudah termasuk di dalam kurikulum sekolah melalui mata pelajaran seni budaya dan keterampilan, bahkan pada Kurikulum 2013 ada mata pelajaran prakarya dan kewirausahaan. Se- 
lain melalui mata pelajaran, psikomotor juga diajarkan melalui kegiatan ekstrakurikuler pada sore hari. Sekolah memberikan kesempatan kepada setiap siswa untuk memilih ekstrakurikuler yang diinginkan sesuai dengan minat. Namun jumlah ekstrakurikuler yang ada tergantung dari keadaan sekolah tersebut.

Ekstrakurikuler di SMA X mencakup kegiatan keagamaan, keolahragaan, kepemimpinan, seni, komputer, kelompok ilmiah remaja, majalah kreasi, bahasa Korea, dan Tirto English Club (TEC). Di SMA Y hanya ada ekstrakurikuler pramuka, bola basket, dan voli, sedangkan di SMA Z menyelenggarakan tapak suci dan hizbul wathan. Strategi lain yang dibuat SMA $X$ dalam mengembangkan aspek psikomotor melalui program weekend show dan porseni sekolah. Program tersebut selain sebagai hiburan siswa juga sebagai ajang untuk menunjukkan keterampilan siswa seperti dari tarik suara, tarian, atau yang lainnya.

\section{Dimensi konteks}

Secara umum struktur internal sekolah terdiri dari kepala sekolah, guru, dan staf tata usaha. Apabila dicermati sebenarnya setiap komponen sekolah tersebut memiliki strategi tersendiri untuk melaksanakan tugas masing-masing. Setiap komponen akan saling bersinergi sehingga pengelolaan sekolah dapat berjalan dengan efektif dan efisien sebagai bagian dari upaya untuk mewujudkan visi dan misi sekolah.

Kepala sekolah pada dasarnya berupaya mengembangkan kultur dan iklim akademik di sekolah. SMA X dan SMA Y menerapkan aturan dengan konsekuensi pemberian reward dan punishment bukan hanya untuk siswa tetapi juga untuk guru. Berbeda dengan SMA Z yang tidak dapat memberlakukan hal tersebut. Penyebabnya sekolah tidak memiliki cukup dana untuk reward sedangkan punishment dipandangkan akan membuat siswa takut ke sekolah sehingga sementara ini kedisiplinan diajarkan dengan keteladanan guru-gurunya.

Iklim akademik juga berupaya diwujudkan kepala sekolah dengan strategi memberikan pelatihan kepada guru untuk mengembangkan kompetensinya, baik dengan kesempatan melanjutkan studi atau dapat melalui kerja sama dengan komunitas MGMP, dan pelatihan-pelatihan seperti TI dan workshop. Bahkan di ketiga sekolah ada program keakraban yang sifatnya memang diadakan sewaktu-waktu dengan maksud agar terjalin sebuah komitmen untuk mengembangkan sekolah dengan berlandaskan pada kekeluargaan.

Guru dan staf tata usaha berada di bawah struktur tugas kepala sekolah sehingga berkewajiban melaksanakan apa yang diperintahkan oleh pimpinan. Namun keduanya sebenarnya juga dapat memiliki strategi tersendiri untuk melaksanakan tupoksinya. Guru bertugas membuat pembelajaran yang aktif, inovatif, kreatif, efektif, dan menyenangkan di kelas sehingga guru dapat menggunakan berbagai media dan model pembelajaran seperti buku, LCD, internet bahkan dengan melakukan kunjungan study. Sedangkan staf tata usaha berupaya menciptakan layanan prima yang memuaskan seluruh pelanggan sekolah.

\section{Ketercapaian Visi Sekolah}

Misi menurut Hidayat \& Machali (2010, p.173) sebagai "kegiatan yang harus dilaksanakan untuk merealisasikan visi yang telah ditetapkan" sehingga peneliti berpandangan misi dapat menjadi indikator untuk melihat ketercapaian dari visi sekolah. SMA X memiliki empat poin misi, berbeda dengan SMA Y dan SMA Z yang memiliki delapan misi untuk mencapai visi sekolah.

Berdasarkan hasil penelitian, misi SMA X sudah dilaksanakan oleh sebagian besar siswa untuk meningkatkan kualitas diri baik dari ketakwaan, prestasi, kepribadian, dan ramah lingkungan. Misi pertama berkaitan dengan ketakwaan dapat dilihat dalam kegiatan kerohanian harian siswa di sekolah. Sikap toleransi dan kerukunan antaragama telah terjalin diantara siswa karena tidak ada perbedaan perlakuan dan diskriminasi. Siswa-siswapun di dalam proses pembelajaran bersaing secara sportif dalam bidang akademik maupun nona- 
kademik. Banyaknya kejuaraan yang dimenangkan siswa-siswa SMA $X$ menunjukkan bahwa misi kedua berkaitan dengan prestasi sudah terwujud.

Berbeda dengan dua misi sebelumnya, misi ketiga yang berkaitan dengan kepribadian memang sedikit sulit untuk diamati karena berkaitan dengan sifat dan sikap siswa yang begitu banyak. Apalagi bisa jadi sikap siswa berbeda jika tidak di depan guru atau di luar sekolah. Namun menurut hasil wawancara nilai kejujuran, kedisiplinan, dan tanggung jawab yang paling dapat diandalkan siswa. Untuk ramah lingkungan, siswa sudah mulai membiasakan diri suka kebersihan meskipun mungkin terkadang masih lupa misalnya untuk menghemat listrik.

SMA Y walaupun visinya mendekati sama dengan SMA $X$ tetapi dilihat dari keterlaksanaan misi masih belum terwujud. Dari delapan misi yang dibuat hanya dua misi yang menurut peneliti sudah mulai berkembang yaitu misi ketiga menciptakan lingkungan sekolah yang aman, rapi, bersih, dan nyaman, serta misi yang kelima mengupayakan pemanfaatan waktu belajar, sumber daya fisik, dan manusia agar memberikan hasil terbaik bagi peserta didik. Hal inipun disebabkan karena kedua misi lebih condong dipengaruhi oleh kerja sama guru-guru, sedangkan misi lain yang berkaitan dengan siswa masih mengalami beberapa kendala. Kesadaran dan kemampuan siswa yang rendah membuat siswa khususnya siswa laki-laki sering malas dan melanggar tata tertib sekolah.

Pencapaian misi SMA Z berdasarkan hasil penelitian lebih baik dari SMA Y. SMA Z merupakan sekolah yang berafiliasi Islam sehingga pembinaan akan ketakwaan termasuk diutamakan. Di sekolah, guruguru berprinsip bahwa akan memberikan materi di kelas berapapun siswa yang hadir. Selain itu siswa diperbolehkan bertanya kepada guru kapanpun itu ketika menemukan kesulitan belajar. Namun yang masih belum dapat dilaksanakan adalah mewujudkan performa sekolah unggul. Hal ini dikarenakan kualitas siswa yang mendaftar memang masih belum dapat bersaing dengan sekolah lain. Siswa SMA $\mathrm{Z}$ berjumlah sedikit dan lebih banyak merupakan hasil saringan yang tidak diterima di sekolah negeri. Pelaksanaan program 6K sedang berupaya diupayakan dengan terus memperbaiki sarana dan prasarana sekolah.

Berdasarkan paparan tersebut, visi ketiga sekolah dapat disimpulkan belum tercapai. Hal ini dikarenakan unsur-unsur yang ada di dalam visi belum sepenuhnya terwujud dengan optimal. Sekolah masih berupaya mewujudkan visi dengan strategi-strategi yang diharapkan dapat meningkatkan ketercapaian sesuai dengan harapan. Visi merupakan rencana jangka panjang sehingga sekolah butuh waktu untuk menggapainya.

\section{Faktor-Faktor yang Mempengaruhi}

Ada beberapa faktor yang mempengaruhi ketercapaian dari visi dan misi sekolah diantaranya:

1. Manusia

Untuk menjalankan manajemen sekolah yang efektif dan efisien, diperlukan manusia yang memiliki kompetensi yang sesuai dengan kapasitas yang diharapkan. Setiap lini harus sesuai dengan kualifikasinya misalnya guru minimal lulusan S1 dan memiliki kualifikasi untuk mengajar sesuai dengan bidangnya. SMA $X$ dan SMA $Z$ sudah menerapkan hal tersebut namun berbeda dengan SMA Y yang gurunya masih ada yang belum S1.

Kemampuan guru dalam menguasai teknologi informasi juga sangat mempengaruhi ketercapaian visi dan misi sekolah. Penggunaan media pembelajaran dirasa dapat menarik minat siswa sehingga prestasi siswa dapat meningkat. Faktor lain yang mempengaruhi ketercapaian visi dan misi sekolah adalah komitmen warga sekolah untuk kemajuan dan berkembangnya sekolah khususnya dalam rangka mewujudkan visi dan misi. Komitmen ini dapat berupa menjalankan tugas dengan tanggung jawab, melaksanakan tata tertib, dan dapat berupaya mengembangkan potensi 
diri sendiri baik oleh kepala sekolah, guru, karyawan, dan siswa.

\section{Pendanaan}

Perbedaan yang peneliti temukan diantara ketiga sekolah adalah terkait dengan pendanaan sekolah. Sumber dana SMA X lebih banyak berasal dari bantuan pemerintah baik daerah maupun pusat, lalu ditambah dari orang tua siswa yang memberikan sumbangan. Berbeda dengan SMA Y dan SMA Z yang merupakan sekolah swasta sehingga sumber dana lebih banyak mencari sendiri yang berasal dari donatur sedangkan dana dari pemerintah lebih sedikit. Besarnya pendanaan yang dimiliki sekolah secara langsung akan mempengaruhi cepat atau lambatnya terwujudnya visi dan misi sekolah karena dana yang lancar akan membuat programprogram dapat berjalan sesuai dengan target waktu. Hal ini sesuai dengan pandangan Wanjala \& Rarieya (2014, p.17) bahwa sumber daya keuangan menjadi salah satu faktor yang mempengaruhi perencanaan strategis sekolah.

\section{Metode}

Pemilihan metode dalam proses pembelajaran di sekolah tidak boleh dilupakan oleh pendidik. Guru harus mengetahui karakter siswa sehingga dapat memilih metode mengajar yang efektif dan efisien karena mengajar bukan hanya dilakukan di dalam kelas melainkan juga di luar kelas. Di dalam kelas, guru memberikan pengetahuan yang dapat diukur dengan hasil ulangan, berbeda dengan di luar kelas yang harus menanamkan nilai kepribadian dan karakter melalui contoh perilaku yang baik. Guru-guru di ketiga sekolah selalu berupaya memotivasi siswa agar terus berkembang dan meningkatkan prestasi baik akademik maupun nonakdemik. Bahkan guru berusaha mengoptimalkan fasilitas yang terkadang minim agar siswa tetap dapat belajar.

\section{Sarana Prasarana}

Salah satu bagian penting dari sekolah adalah ketersediaan sarana dan prasa- rana pendidikan yang layak. Ketersediaan sarana dan prasarana yang mencukupi dan baik dapat mempercepat terwujudnya visi dan misi sekolah karena mendukung program-program yang berkaitan dengan proses pembelajaran siswa. SMA $X$ termasuk sekolah yang memiliki sarana dan prasarana yang lengkap diantaranya dari ruang kelas, perpustakaan, laboratorium IPA, ruang ibadah, sampai UKS dan koperasi tersedia. Bahkan setiap ruang kelas telah dipasangkan LCD permanen dan dilengkapi oleh pendingin ruangan (AC).

Ketersediaan sarana dan prasarana memang berkaitan dengan jumlah dana yang dimiliki sekolah. SMA Y dan SMA Z yang pendanaannya minim belum dapat memiliki ruang-ruang pendukung seperti laboratorium IPA dan perpustakaan yang baik. Guru-guru dalam memberikan materi pelajaran masih memanfaatkan buku-buku pegangan dan belum terlalu banyak menggunakan bantuan LCD karena keterbatasan fasilitas dan kemampuan guru sendiri.

\section{Kepemimpinan}

Kepala sekolah di ketiga sekolah baik SMA X, SMA Y, dan SMA Z berupaya menjadi pemimpin yang baik dengan melaksanakan tugas-tugas sebagai manajer dan sebagai leader. White (2004, p.38) mengungkapkan strategi berkaitan dengan kerja sama tim dan fungsi kepemimpinan untuk memandu dan memotivasi tim. Kepala sekolah memegang peran penting dalam proses mewujudkan visi dan misi sekolah karena strategi yang dibuat mengacu pada prioritas-prioritas yang diinginkan. Selain itu semua rencana yang dibuat sekolah keputusan sampai pada pengelolaan dana dan perizinan harus melalui keputusan kepala sekolah.

\section{Komunikasi}

Faktor terakhir yang menurut peneliti mempengaruhi ketercapaian visi dan misi sekolah adalah terjalinnya komunikasi yang baik diantara para stakeholder. Nawawi (2005, p.99) mengartikan komunikasi sebagai "proses penyampaian dan penerimaan informasi yang menjadi salah 
satu sumber daya untuk menjaga, memelihara, memajukan, dan mengembangkan organisasi secara dinamis sesuai dengan tujuannya." Rosyadi (2015, p.133) juga menegaskan bahwa kurangnya komunikasi kepala sekolah dengan personil dapat menjadi penghambat peningkatan mutu sekolah.

SMA X setiap Senin pagi ada breafing yang menjadi ajang bertukar informasi baik dari kepala sekolah maupun guru dan karyawan. Komunikasi dengan para siswa juga dimudahkan dengan adanya kotak saran dan mading yang dikelola oleh pengurus OSIS. Untuk komunikasi dengan orang tua, komite, dan masyarakat, sekolah membuat pertemuan setiap akhir semester dalam rangka membahas perkembangan sekolah sehingga seluruh pihak dapat mengetahui keadaan sekolah secara jelas.

Di SMA Y dan SMA Z juga sama berupaya menjalin komunikasi dengan seluruh pihak yang berkepentingan. Komunikasi biasanya dilakukan melalui acara pengajian yang lebih sering dilanjutkan dengan membahas perkembangan siswa. Guru-guru berupaya menjadi teman, kakak, dan orang tua siswa di sekolah untuk dapat mengetahui keadaan siswa. Hal ini bertujuan untuk memotivasi siswa dalam berprestasi di sekolah. Rapat dan pertemuan untuk evaluasi juga rutin dilakukan walaupun berdasarkan hasil penelitian, sekolah sedikit mengalami kesulitan dalam mengundang orang tua siswa.

\section{Strategi yang Efektif}

Pengelolaan sekolah berkaitan dengan perencanaan sampai pada pengendalian yang berawal dari visi dan misi sekolah. Menurut peneliti, kepala sekolah dapat melakukan beberapa hal berikut sebagai strategi dalam upaya mewujudkan visi sekolah diantaranya:

1. Membangun Harapan Individu Menjadi Visi Bersama

Di lingkungan pendidikan, kepala sekolah diharapkan memiliki visi tersendiri dalam upaya mengembangkan sekolah khususnya untuk mewujudkan visi seko- lah. Tantangan yang dihadapi kepala sekolah saat ini adalah karakter bawahan yang terkadang bermacam-macam, kebutuhan masyarakat yang kian berkembang, dan juga tuntutan pemerintah yang terkadang dilandasi oleh kepentingan golongan. Vally \& Daud (2015, p.693) menyebutkan bahwa kepala sekolah yang lebih efektif melaksanakan perannya, maka akan semakin efektif pelaksanaan visi dan misi dengan pengelolaan sumber daya manusia.

Kepala sekolah dapat memberikan kesempatan kepada guru dan karyawan menuliskan harapannya masing-masing tentang keadaan sekolah yang diinginkan di masa depan atau masalah yang dihadapi. Archbald (2013, p.136) menyimpulkan "kertas pernyataan masalah merupakan salah satu yang dapat mengembangkan pengetahuan substantif dan komunikasi terkait visi." Berdasarkan hal tersebut dapat terlihat visi dari setiap orang sehingga perubahan apa yang perlu dibuat dapat dirumuskan bersama.

Komitmen akan muncul jika seluruh pihak dilibatkan dalam pengelolaan sekolah, termasuk dalam proses pengambilan keputusan. Memang kepala sekolah diakui sebagai sosok sentral yang menentukan hasil dari keputusan yang diambil. Namun perlu diperhatikan bahwa peran guru dan karyawan termasuk menentukan keberhasilan rencana yang dibuat. Adanya keterbukaan dan pemberian kesempatan membuat guru dan karyawan merasa memiliki andil dan bertanggung jawa terhadap keputusan yang telah dibuat bersama.

2. Membuat Prioritas Pembangunan dengan Indikator Ketercapaiannya

Visi pada dasarnya berkaitan dengan keadaan di masa depan yang ingin dicapai sekolah. White (2004, p.55) memandang "visi yang jelas merupakan prasyarat untuk perumusan strategi yang baik." Sekolah tidak dapat mewujudkan keseluruhan visi secara keseluruhan, oleh sebab itu perlu adanya prioritas yang ditetapkan untuk dibangun terlebih dahulu. Kepala sekolah sebagai pemimpin biasanya yang memegang kendali untuk menentukan apa 
dan bagian mana yang ingin dibangun. Namun yang perlu diperhatikan bahwa kepala sekolah harus menentukan prioritas sesuai dengan kebutuhan dan melihat sumber daya yang dimiliki sekolah.

\section{Membangun Motivasi Berprestasi}

Salah satu yang perlu dibangun kembali menurut peneliti adalah motivasi berprestasi dari guru. Lunenburg \& Ornstein (2013, p.80) mendefinisikan "motivasi sebagai proses yang merangsang dan menyalurkan perilaku individu untuk keunggulan organisasi." Saat ini proses pembelajaran di sekolah masih dianggap sebagai rutinitas untuk menggugurkan kewajiban oleh guru. Kepala sekolah perlu mencari terobosan agar guru kembali termotivasi. Salah satunya dengan reward dan bentuknya tidak harus memberikan uang tetapi dapat dengan penghargaan, jabatan, atau kesempatan menempuh pendidikan lanjutan.

\section{Meningkatkan Partisipasi Orang Tua dalam Penanaman Nilai-Nilai}

Keberhasilan pendidikan siswa tidak dapat hanya mengandalkan proses pembelajaran di sekolah, tetapi juga harus dikembangkan di lingkungan keluarga. Keluarga merupakan tempat siswa lebih banyak mendapatkan penanaman nilai-nilai religius, sosial, maupun sikap, sedangkan sekolah terbatas pada jam pelajaran. Orang tua harus membiasakan kehidupan keluarga sebagaimana dilaksanakan di sekolah. Hal ini membuat sekolah perlu bekerja sama dengan orang tua untuk memonitoring perkembangan siswa sehingga akan cepat diketahui jika ada ke-majuan atau sebaliknya kemunduran. Hal ini sesuai dengan pandangan Lunenburg \& Ornstein (2013, p.80) bahwa partisipasi merupakan salah satu dari enam strategi untuk menghadapi perubahan.

5. Membangun Kemitraan dengan Berbagai Pihak

Proses pembelajaran merupakan inti dari penyelenggaraan pendidikan di sekolah. Untuk meningkatkan kualitas pembel- ajaran sekolah memang harus banyak melakukan terobosan. Sementara ini sekolah lebih banyak menilai rendahnya kualitas berdasarkan input siswa dan kompetensi guru. Padahal menurut peneliti, sekolah dapat lebih kreatif dengan membangun kemitraan dengan berbagai pihak yang mereka butuhkan. Morse (1993, p.9) memandang keterlibatan orang-orang kritis agar berpartisipasi menjadi salah satu langkah dalam pengembangan visi. Kemitraan yang dibangun diusahakan bukan hanya berhubungan dengan pendidikan saja seperti kampus dan dinas terkait tetapi juga dengan lembaga kesehatan, hukum, usaha masyarakat, dan seni budaya.

\section{Simpulan dan Saran}

\section{Simpulan}

Proses perumusan visi dan misi sekolah dilakukan melalui rapat internal yang dibuat oleh kepala sekolah. Di dalam rapat, dibuat tim yang terdiri dari wakil kepala sekolah dan beberapa guru yang memiliki tugas untuk mengumpulkan informasi dari berbagai sumber dengan memperhatikan beberapa hal seperti visi lembaga yang ada di atas sekolah, nilainilai dalam masyarakat, dan relevansi dengan tuntutan dan perkembangan zaman. Gagasan pernyataan visi hasil rapat kemudian dipaparkan dalam pertemuan yang melibatkan seluruh stakeholder termasuk komite, yayasan, orang tua, dan perwakilan Dinas Pendidikan Bantul.

Strategi yang dibuat sekolah dalam upaya mewujudkan visi dan misi melalui proses yang sama yaitu perencanaan, pengorganisasian, pelaksanaan, dan pengendalian. Konten strategi sekolah secara umum dapat dimasukkan dalam aspek spiritual, kognitif, afektif, dan psikomotor. Konteks strategi yang dibuat oleh kepala sekolah, guru, dan tata usaha memiliki tujuan akhir memberikan pelayanan yang memuaskan siswa agar dapat mempersiapkan bekal ilmu pengetahuan, keterampilan, dan nilainilai luhur sehingga dapat digunakan untuk melanjutkan ke pendidikan tinggi atau diaplikasikan dalam masya-rakat. 
Ketercapaian dari visi yang telah dibuat ketiga sekolah dapat dikatakan belum tercapai. Hal ini dikarenakan unsurunsur yang ada di dalam visi belum sepenuhnya terwujud dengan optimal. Ketercapaian visi dan misi dipengaruhi oleh beberapa faktor diantaranya sumber daya manusia, pendanaan, metode, sarana prasarana, kepemimpinan sekolah, dan juga komunikasi diantara semua lini.

Kepala sekolah dapat melakukan beberapa hal sebagai strategi dalam upaya mewujudkan visi sekolah diantaranya: (1) membangun harapan individu menjadi visi bersama, (2) membuat prioritas pembangunan dengan indikator ketercapaiannya,

(3) membangun motivasi berprestasi, (4) meningkatkan partisipasi orang tua dalam penanaman nilai-nilai, (5) membangun kemitraan dengan berbagai pihak.

\section{Saran}

Terkait dengan strategi sekolah dalam upaya mewujudkan visi dan misi sekolah, kepala sekolah perlu menyatukan visi warga sekolah agar tercipta shared vision sehingga menimbulkan komitmen dalam upaya mewujudkannya. Selain itu kepala sekolah dan guru perlu mencari alternatif punishment yang akan diberikan kepada siswa sehingga membuat siswa belajar dari kesalahannya seperti dengan meminta meresume sebuah buku dan menceritakan isi buku ketika pelajaran di depan kelas.

\section{Daftar Pustaka}

Akil. (2007). Pengaruh visi dan misi, gaya kepemimpinan kepala sekolah, komitmen guru pada tugas, dan latar belakang sosekbud terhadap kinerja guru dan hubungannya dengan kualitas hasil belajar siswa. Disertasi: Universitas Pendidikan Indonesia, Indramayu.

Archbald, D. (2013). Vision and leadership: problem-based learning as a teaching tool. Journal of Leadership Education, 12, 136-147.
Danim, S. (2007). Visi baru manajemen sekolah: dari unit birokrasi ke lembaga akademik. Jakarta: Bumi Aksara.

David, R.F. (2011). Strategic management: concepts and cases (13 thed.). New Jersey: Pearson Education, Inc.

Dikpora D.I.Y. (2013). Rencana strategis dinas pendidikan, pemuda, dan olahraga Daerah Istimewa Yogyakarta tahun 2012-2017. Diambil pada 3 Januari 2015, dari http://www.pendidikandiy.go.id/dinas_v4/file/renstra/re nstra_2012-2017.pdf.

Fidler, Brian. (2002). Strategic management for school development: leading your school's improvement strategy. London: Paul Chapman Publishing.

Hannagan, Tim. (2002). Mastering strategic management. New York: Palagrave.

Hidayat, A., \& Machali, I. (2010). Pengelolaan pendidikan: konsep, prinsip, dan aplikasi dalam mengelola sekolah dan madrasah. Bandung: Pustaka Educa.

Kantabutra, S. (2012). Relating shared vision components to thai public school performance. The Journal of Applied Businness Reseach, 28, 11591170.

Lunenburg, F.C. \& Ornstein, A.C. (2012). Educational admonistration: concepts and practices, sixth edition. Wadsworth: Wadsworth Cengange learning.

Menteri Pendidikan Nasional. (2007). Peraturan menteri pendidikan nasional RI Nomor 19, Tahun 2007, tentang Standar Pengelolaan oleh Satuan Pendidikan Dasar dan Menengah.

Morse, S. M. (1993). Vision, leadership, and change. Issues about Change, 2, 1-9.

Nawawi, H. (2005). Manajemen strategik: organisasi nonprofit bidang pemerintahan dengan ilustrasi di bidang pendidikan. Yogyakarya: Gadjah Mada University Press. 
Obong, L. B., Okey, A. M., Aniah, E. J., et al. (2010). Strategies for school environmental management in nigerian secondary schools: a case of calabar, Nigeria. International Education Studies, 3, 196-205.

Rivai, V., \& Murni, S. (2012). Education management: analisis teori dan praktik. Jakarta: Raja Grafindo Persada.

Rosyadi, Y. I., \& Pardjono. (2015). Peran kepala sekolah sebagai manajer dalam meningkatkan mutu pendidikan di smp 1 cilawu garut. Jurnal Akuntabilitas Manajemen Pendidikan, 3, 133-142.

Sallis, E. (2010). Total quality management in education. Yogyakarta: IRCiSoD.

Sugiyono. (2014). Metode penelitian manajemen. Bandung: Alfabeta.

Unesco. (2015). Incheon declaration, education 2030: towards inclusive and equitable quality education and lifelong learning for all. Word Education Forum 2015. Diambil pada tanggal 11 Juli 2015, dari http://unesdoc.unesco.org/images /0023/002331/233137e.pdf.

Vally, V. S., \& Daud, K. (2015). The implementation of school based management policy: an exploration. Procedia, 172, 693-700.

Wanjala, C.N \& Rarieya, J.F.A. (2014). Strategic planning in schools in kenya: possibilities and challenges. ISEA, 42, 17-30.

White, C. (2004). Strategic management. New York: Palgrave Macmilan.

Zamroni. (2007). Meningkatkan mutu sekolah: teori, strategi, dan prosedur. Jakarta: PSAP Muhammadiyah. 